\title{
Anaphylactoid reaction to maltose $5 \%$ solution during spinal anaesthesia
}

\author{
Mikiko Enokibori $\mathrm{MD},{ }^{*}$ \\ Makoto Kuge MD, * \\ Kenjiro Mori MD FRCA ${ }^{\dagger}$
}

Purpose: A rare case of an anaphylactoid reaction to maltose solution is presented.

Clinical features: A 28-yr-old man undenwent repair of bilateral inguinal hernia under spinal anaesthesia with dibucaine. At the end of operation, he developed generalized flush and circulatory collapse immediately after receiving $\mathrm{Na}$ acetate solution containing maltose, $5 \%$, iv. The reactions were treated with $32 \mathrm{mg}$ ephedrine and $250 \mathrm{mg}$ methylprednisolone iv, and rapid infusion of $1,000 \mathrm{ml}$ acetated Ringer's solution. The skin tests provoked positive responses to maltose solutions.

Conclusion: The clinical features and skin tests suggested that the episode was an anaphylactoid reaction to maltose. Maltose is one of the dissacharides (MW: 342) produced from starch and glycogen. Maltose solutions are used frequently in Japan as a carbohydrate source. Further study is required to confirm whether maltose has an immunological antigen-eliciting activity.

Objectif : Présenter une rare observation de réaction anaphylactoïde au maltose.

Éléments cliniques : Un homme de 28 ans a subi une cure bilatérale de hernie inguinale sous rachianesthésie à la dibucaiine. À la fin de l'intervention, il a présenté un érythème généralisé et un collapsus circulatoire après l'administration d'acétate de $\mathrm{Na}$ contenant du maltose à $5 \% \mathrm{iv}$. La réaction a été traitée avec $32 \mathrm{mg}$ d'éphédrine et $250 \mathrm{mg}$ de méthylprednisolone iv avec une perfusion rapide de $1000 \mathrm{ml}$ d'une solution de Ringer avec acétate. L'intradermoréaction était positive aux solutions de maltose.

Conclusion : Les élément cliniques et les épreuves cutanées suggèrent une réaction anaphylactoïde au maltose. Le maltose est un dissacharide (PM : 342) provenant de l'amidon et du glycogène. Au Japon, on administre souvent des solutions de maltose comme sources d'hydrates de carbone. Des épreuves supplémentaires sont nécessaires pour confirmer l'action antigénique du maltose.

From the Department of Anesthesiology, ${ }^{*}$ Mitsubishi Kyoto Hospital and Department of Anesthesia, ${ }^{\dagger}$ Kyoto University Hospital. Address correspondence to: Dr. Kenjiro Mori, Department of Anesthesia, Kyoto University Hospital, Sakyo-Ku, Kyoto, 606-01; Japan. Phone: 81-75-751-3433; Fax: 81-75-752-3259; E-mail: kmori@kuhp.kyoto-u.ac.jp Accepted for publication October 2, 1997. 


\section{A} NAESTHETISTS may encounter acute life-threatening allergic reactions, i.e., anaphylaxis or anaphylactoid reactions, during anaesthesia. The incidence is increasing recently because of use of a greater number of drugs perioperatively. ${ }^{1,2}$ Allergic reactions to intravenous infusion are, however, rare. Maltose solution has been used widely in Japan as a carbohydrate source, which provides energy of twice the mass of sugar (and of calories) per millilitre as an equimolar solution of glucose. $^{3}$ More than 15 million litres are estimated to be consumed each year, without serious adverse reactions. The present report is a case of anaphylactoid reaction to maltose solution.

\section{Case report}

A 28-yr-old man, weight $60 \mathrm{~kg}$, height $172 \mathrm{~cm}$, was scheduled for repair of bilateral inguinal hernias. Four months before the present admission, the patient was given $2 \mathrm{~g}$ cefotiam (antibiotics), and $250 \mathrm{ml}$ lactated Ringer's solution with maltose $5 \%$ iv, for acute epididymitis. This infusion was followed by swelling and erythema over the face and legs, for which $250 \mathrm{mg}$ methylprednisolone, and $20 \mathrm{mg}$ glycchizinate $i v$, were effective. No cardiovascular and respiratory changes were noted during this reaction. Intradermal testing of cefotiam before surgery was negative. Physical examination and laboratory tests revealed no abnormalities.

No preanaesthetic medication was given. Electrocardiographic leads, a blood pressure cuff, and a transcutaneous pulse oximeter were placed on arrival at the operating room and an intravenous infusion of acetated Ringer's solution was started. Blood pressure was $120 / 70 \mathrm{mmHg}$ and heart rate 72 beats $\mathrm{min}^{-1}$. Dibucaine, $7.2 \mathrm{mg}$ in $3 \mathrm{ml}$ (of glucose $10 \%$ ), was injected intrathecally at the L 3-4 interspace. Analgesia to pinprick reached $\mathrm{T} 6$ at five minutes. Blood pressure and heart rate were stable at $100 / 58 \mathrm{mmHg}$ and 80 beats $\cdot \mathrm{min}^{-1}$. Midazolam, $5 \mathrm{mg}$, was administered $i v$ for sedation. Ephedrine, $8 \mathrm{mg}$ iv, was given to maintain blood pressure $15 \mathrm{~min}$ later. The patient was fully stable for one hour. After the operation was over at $1 \mathrm{hr} 15 \mathrm{~min}, 0.3 \mathrm{mg}$ flumazenil ip was administered and the patient regained consciousness. The Ringer's acetate solution, $1,000 \mathrm{ml}$, was followed by $\mathrm{Na}$ acetate solution containing maltose $\mathbf{5 \%}$. A few minutes later, blood pressure decreased precipitously to $70 / 36$ $\mathrm{mmHg}$ and heart rate slowed to 40 beats. $\mathrm{min}^{-1}$. Oxygen was administered via face mask, $400 \mathrm{ml}$ maltose-containing solution was infused rapidly and a total of $32 \mathrm{mg}$ ephedrine was given iv, but blood pressure further decreased to $46 / 20 \mathrm{mmHg}$. A gener- alised erythematous rash was noted at that time, and anaphylaxis was suspected. Methylprednisolone, $500 \mathrm{mg}$, was administered ip and the maltose-containing solution was replaced with acetated Ringer's solution, $1,000 \mathrm{ml}$, which was infused rapidly. Blood pressure and heart rate returned close to the control level within $15 \mathrm{~min}$. During this episode, the patient was conscious and did not complain of dyspnea. There was no audible wheezing, and $\mathrm{SpO}_{2}$ remained at 99-100\% with 1.0 of $\mathrm{F}_{\mathrm{I}} \mathrm{O}_{2}$. Vital signs remained stable over the next $30 \mathrm{~min}$. The erythema persisted for five hours and faded gradually.

The patient consented to skin tests with prick and intradermal injection to $\mathrm{Na}$ acetate solution with maltose $5 \%$, lactated Ringer's solution with maltose $5 \%$, maltose $10 \%$ solution, dextrose $10 \%$ solution, cefotiam, dibucaine, and flumazenil which were performed four weeks later by a dermatologist. Each solution was prepared with undiluted and tenfold serial dilution. Normal saline solution served as a negative and histamine solution $\left(0.01 \mathrm{mg} \cdot \mathrm{ml}^{-1}\right)$ as a positive control. In the prick tests, the patient demonstrated positive responses to maltose solutions: flare of $10 \times 15 \mathrm{~mm}$ in diameter to $0.1 \mathrm{mg} \cdot \mathrm{ml}^{-1}$ maltose solution and $15 \times 20$ flare to $100 \mathrm{mg} \cdot \mathrm{ml}^{-1}$ maltose solution (the photographs were poor in quality and are not shown). Prick tests to the other agents were all negative. In the intradermal tests to serial diluted maltose solutions, the patient demonstrated negative responses to 0.1 and $1 \mathrm{mg} \cdot \mathrm{ml}^{-1}$ solutions, and positive responses to a $10 \mathrm{mg} \cdot \mathrm{ml}^{-1}$ solution; a wheal of $7 \times 10 \mathrm{~mm}$ and flare of $17 \times 20 \mathrm{~mm}$ in diameter (see Figure).

A whole-blood histamine-release test was performed. Results expressed as a percentage of total histamine are considered positive when $>20 \%$ of total histamine has been released. ${ }^{4}$ In this case, maltose released $3.8,4.2$ and $4.1 \%$ of total histamine from whole blood in the presence of 10,1 and $0.1 \mathrm{mg} \cdot \mathrm{ml}^{-1}$ maltose solutions, respectively.

\section{Discussion}

The patient demonstrated rapid development of generalised flush and hypotension after receiving $\mathrm{Na}$ acetate solution containing maltose $5 \%$ iv. He had suffered a similar though milder reaction to lactated Ringer's solution with maltose $5 \%$ on a previous occasion. The clinical features and history indicated that the episode was an anaphylactic or anaphylactoid reaction to iv maltose.

Skin testing is most frequently used for identifying the causative agent of allergic reactions. ${ }^{5-9}$ In the present case, even the most dilute concentration of 


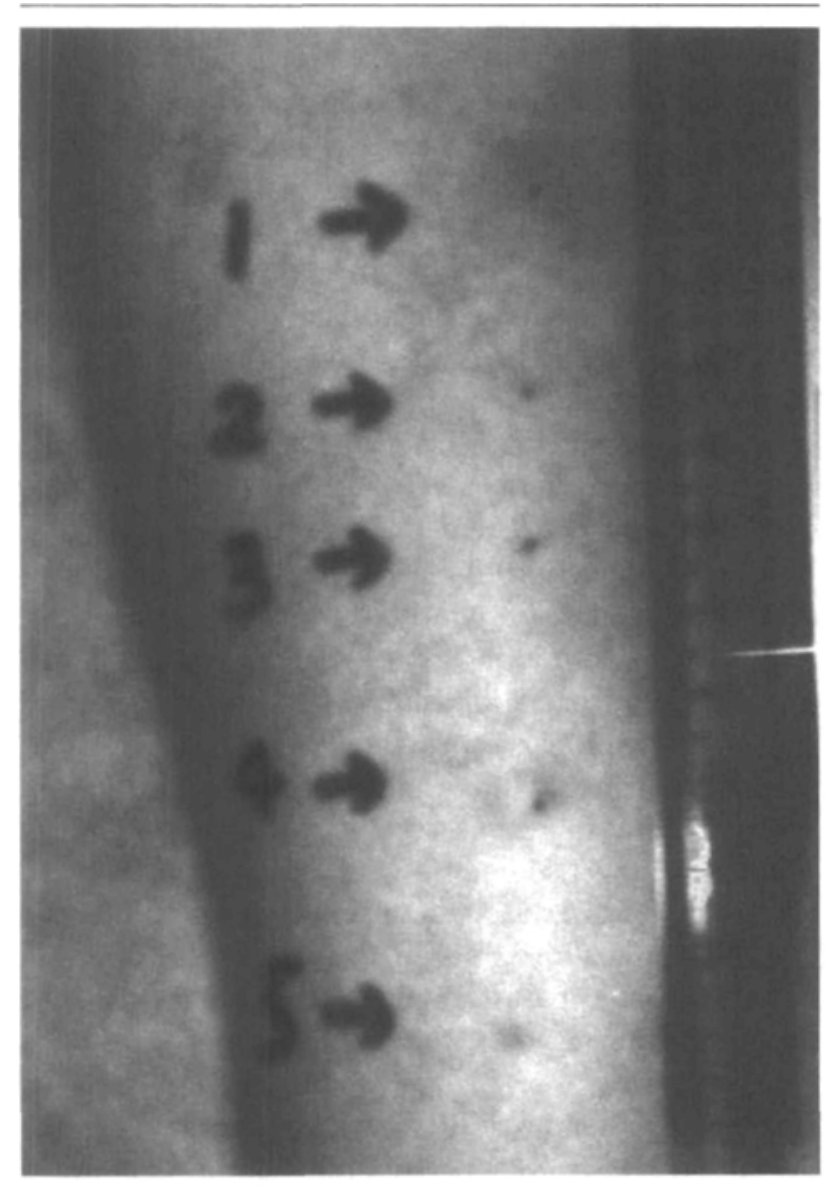

FIGURE Intradermal testing on the right arm of the patient. Arrow 1 represents a positive reaction to $10 \mathrm{mg} \cdot \mathrm{ml}^{-1}$ maltose solution; arrows 2 and 3 negative reactions to 1 and $0.1 \mathrm{mg} \cdot \mathrm{ml}^{-1}$ solution respectively; arrow 4 the positive control to histamine solution; and arrow 5 a negative one to normal saline solution.

maltose produced positive responses in the prick test, while only the highest concentration produced positive response in the intra-dermal test. It is generally agreed that the intradermal test gives positive, or more correctly false-positive response by a direct pharmacological histamine release. This was not the case in present study, and the intradermal tests gave negative results to the concentration that provoked positive response in the prick test. No explanation is available for these paradoxical findings. Although the prick test appears to be less sensitive, it seeks essentially antigenic recognition from sensitised lymphocytes, $7,8,10$ and the positive response in the prick test in the present patient confirmed maltose as the causative agent.

The histamine-release test was negative in the present study. The concentration of maltose used in the test, i.e., 10,1 and $0.1 \mathrm{mg} \cdot \mathrm{ml}^{-1}$, was based on an assumption that the reaction begins to occur when approximately $50 \mathrm{ml}$ maltose $5 \%$, i.e., $2.5 \mathrm{~g}$ of maltose, is administered to a man of $60 \mathrm{~kg}$. In most clinical studies, a close correlation has been noted between the results of skin tests and the histaminerelease test. ${ }^{4}$ The failure of the present histaminerelease test may possibly be referred to the difficulty to perform, and furthermore, to the possible presence of antibodies that compete for antigen and prevent it from reaching the IgE-sensitised basophils. ${ }^{4}$ The rate of false-negative has been reported $20 \%{ }^{4}$

Airway maintenance, oxygen administration, rapid intravenous infusion of crystalloid and/or colloid solutions of $>10 \mathrm{ml} \cdot \mathrm{kg}^{-1}$, and epinephrine are the mainstay of treatment. The severity of symptoms reflects the quantity of mediators released. ${ }^{1}$ Beta-adrenergic receptor stimulation increases the intracellular cyclic AMP of the basophils and mast cells, which phosphorylates the $\mathrm{Ca}^{2+}$ pump protein, and suppresses the mediator release. Intravenous epinephrine, initial dose 50-100 $\mu \mathrm{g}$ in adults, $10 \mu \mathrm{g} \cdot \mathrm{kg}^{-1}$ in children, should be given immediately. Repeated administration or infusion of epinephrine, $0.05-0.10 \mu \mathrm{g} \cdot \mathrm{kg}^{-1} \cdot \mathrm{min}^{-1}$, may also be required. ${ }^{2,11}$ Subcutaneous or intramuscular injection of $50 \mu \mathrm{g} \cdot \mathrm{kg}^{-1}$ epinephrine, is an alternative to intravenous administration in less severe reactions ${ }^{1}$ as arrhythmias occur. The arrhythmias are caused by an $\mathrm{H}_{2}$ dysrhythmogenic effect of histamine on the atria and ventricles. ${ }^{2}$ In the present case, at the initial stage of the reaction, we could not realize the occurrence of anaphylaxis or anaphylactoid reaction, and ephedrine was given in the usual dose for mild hypotension induced by spinal anaesthesia. Consequently, a considerable dose of ephedrine was required. Hypotension in this case was mild and rapid intravenous volume expansion with Ringer's acetate solution restored BP to the control level. Although corticosteroids are often administered for the treatment of allergic reaction, their theoretical value in acute phase is, at present, difficult to defend.

The patient had stable blood pressure without vasopressors under spinal anaesthesia to T6 for over one hour. However, the peripheral sympathetic block would prevent compensatory vasoconstriction and thus exaggerate the magnitude of hypotension as suggest by Stoelting. ${ }^{1}$

Several reviews have appeared on the use of maltose infusions. ${ }^{3,13,14}$ It is a disaccharide and is found in cereal products and glucose syrups. ${ }^{12}$ Intravenously administered maltose is transported into the cells partly independent of insulin, and then gradually hydrolysed to two glucose molecules. ${ }^{3,14}$ In Japan, maltose solution is commercially available and is used frequently, approximately $>15$ million litres per annum. The incidence of 
adverse responses is extremely low, and only two cases have been reported. ${ }^{15,16}$ Both occurred following repeated administration, developed serious reactions, and skin tests indicated that maltose was responsible. No study has succeeded in identifying the antigenicity of maltose. Further investigation is required to confirm whether maltose has an immunological antigen-eliciting activity. Anaesthetists must always be alert to the possible occurrence of such allergic reactions even to the components of intravenous infusion.

\section{References}

1 Stoelting $R K$. Allergic reactions during anesthesia. Anesth Analg 1983; 62: 341-56.

2 Withington $D E$. Allergy, anaphylaxis and anaesthesia. Can J Anaesth 1994; 41: 1133-9.

3 Weser E, Sleisenger $M H$. Metabolism of circulating disaccharides in man and the rat. J Clin Invest 1967; 46: 499-505.

4 Siraganian RP, Hook WA. Histamine release and assay methods for the study of human allergy. In: Rose NR, Friedman H, Fahey JL (Eds.). Manual of Clinical Laboratory Immunology, 3th ed. Washington, D.C. American Society for Microbiology 1986: 675-84.

5 Kniker WT, Hales SW, Lee LK. Diagnostic methods to demonstrate IgE antibodies: skin testing techniques. Bull NY Acad Med 1981; 57: 524-48.

6 Fisher $M$. Intradermal testing after anaphylactoid reaction to anaesthetic drugs: practical aspects of performance and interpretation. Anaesth Intensive Care 1984; 12: 115-20.

7 Watkins $J$. Investigation of allergic and hypersensitivity reactions to anaesthetic agents. $\mathrm{Br} J$ Anaesth 1987; 59: 104-11.

8 Leynadier $F$, Sansarricq M, Didier JM, Dry J. Prick tests in the diagnosis of anaphylaxis to general anaesthetics. Br J Anaesth 1987; 59: 683-9.

9 Moneret-Vautrin DA, Laxenaire MC. Skin tests in diagnosis of allergy to muscle relaxants and other anesthetic drugs. Monogr Allergy 1992; 30: 145-56.

10 Watkins $J$. Heuristic decision-making in diagnosis and management of adverse drug reactions in anaesthesia and surgery: the case of muscle relaxants. Theor Surg 1989; 4: 212-22.

11 Bochner BS, Lichtenstein LM. Anaphylaxis. N Engl J Med 1991; 324: 1785-90.

12 Southgate DAT. Digestion and metabolism of sugars. Am J Clin Nutr 1995; 62: 203S-11.

13 Young SJM, Weser E. The metabolism of circulating maltose in man. J Clin Invest 1971; 50: 986-91.

14 Sprandel U, Heuckenkamp P-U, Zöllner N. Urilization of intravenous maltose. Nutr Metabol 1975; 19: 96-102.
15 Ishii H, Shima T, Hoshi K, Iwatsuki N, Hasbimoto $Y$. A case of anaphylactoid reactions to lactated Ringer's solution with 5\% maltose. (Japanese) Masui 1989; 38: 1217-21.

16 Kimura $M$, Sunami $K$, Takeda A. Two cases of anaphylactic shock induced by chlorhexidine gluconate and maltose. (Japanese) Masui To Sosei 1994; 30: 319-22. 